\title{
Isolation of Anticancer Compounds from Peucedanum japonicum Thunb. Roots
}

\author{
Neung Jae Jun ${ }^{1,4}$, Seong-Cheol Kim²*, Eun-Young Song ${ }^{1}$, Ki Chang Jang ${ }^{3}$, \\ Dong Sun Lee ${ }^{4}$ and Somi K. Cho ${ }^{4,5}$ \\ ${ }^{1}$ Agricultural Research Center for Climate Change, National Institute of Horticultural \& Herbal Science, Rural \\ Development Administration, Jeju 690-150, Korea \\ ${ }^{2}$ Namhae Sub-Station, National Institute of Horticultural and Herbal Science, RDA, Namhae 668-812, Korea \\ ${ }^{3}$ Research and Development Bureau, RDA, Suwon 441-707, Korea \\ ${ }^{4}$ Faculty of Biotechnology, Jeju National University, Jeju 690-756, Korea \\ ${ }^{5}$ The Research Institute for Subtropical Agriculture and Biotechnology, Jeju National University; Subtropical Horticulture \\ Research Institute, Jeju National University, Jeju 690-756, Korea
}

\begin{abstract}
This study was conducted to isolate a compound with anticancer properties from the roots of Peucedanum japonicum Thunb. (Umbelliferae), and to evaluate the efficacy of that compound's anticancer activity. $\mathrm{The}^{\mathrm{CHCl}_{3}}$ layer was purified via repeated column chromatography and recrystallization. The two compounds isolated from $\mathrm{CHCl}_{3}$ layer were identified via NMR spectroscopic analysis as (10E) 1,10-heptadecadiene-4,6-diyne-3,8,9-triol (Comp. I) and anomalin (Comp. II). (10E) 1,10-heptadecadiene-4,6-diyne-3,8,9-triol was the first report from the roots of P. japonicum. MTT assays were conducted to evaluate the in vitro cytotoxic activities of Compounds I and II against the following human cancer cell lines: HeLa, HepG2, SNU-16, and AGS. Comp. I evidenced the most profound cytotoxic activity against HepG2 cells $\left(\mathrm{IC}_{50}=6.04 \mu \mathrm{g} / \mathrm{mL}\right)$, and Comp. II exhibited the most profound cytotoxic activity against SNU-16 cells $\left(\mathrm{IC}_{50}=18.24 \mu \mathrm{g} / \mathrm{mL}\right)$ among the human cancer cell lines tested in this study. However, no significant cell death was observed in the CCD-25Lu human normal lung fibroblast cells. Quantitative analysis using UPLC (Ultra Performance Liquid Chromatography) showed that the roots of $P$. japonicum contained 0.015 (Comp. I) and $1.69 \mathrm{mg} / \mathrm{g}$ (Comp. II) of these compounds.
\end{abstract}

Key words - Anti-cancer compound, Cytotoxicity, MTT assay, Peucedanum japonicum, UPLC

\section{Introduction}

Traditionally natural products have played an important role in drug discovery. Nature product is an attractive source of new therapeutic candidate compounds. Also, a tremendous chemical diversity has been found in millions of species of plants, animals, marine organisms and microorganisms. Natural products have been invaluable as tools for deciphering the logic of biosynthesis and as platforms for developing frontline drugs (Newman et al., 2000). For example, between 1981 and $2002,5 \%$ of the 1,031 new chemical entities approved as drugs by the US Food and Drug Administration (FDA) were natural products, and another $23 \%$ were natural-product-derived molecules. Vincristine, irinotecan, etoposide and paclitaxel

*Corresponding author. E-mail : kimsec@korea.kr are examples of plant-derived compounds that are being employed in cancer treatment (Newman et al., 2003).

Today, millions of people are living with cancer or cancer patients. In Korea, the incidence of cancers is increasing by western diet and low physical activity. Although the disease has therefore existed for at least several thousand years, its prevalence has been steadily increasing. In just the past 50 years, a person's chance of developing cancer within his or her lifetime has doubled, and doctors are now examining more cases of the disease than ever before. If we live until average life expectancy, the probability of cancer occurrence is $26.1 \%$ ( Kushi et al., 2006).

The oldest description of cancer was discovered in Egypt and dates back to approximately 1600 B.C. The term cancer, which means 'crab' in Latin, was coined by Hippocrates. Cancer develops when cells in a part of the body begin to 
grow out of control. Even though there are many kinds of cancer, they all start because of abnormal cells that grow out of control. Normal body cells grow, divide, and die in an orderly fashion. During the early years of a person's life, normal cells divide more rapidly until the person becomes an adult. After that, cells in most parts of the body divide only to replace worn-out or dying cells and to repair injuries. Because cancer cells continue to grow and divide, they are different from normal cells. Cancer cells often travel to other parts of the body where they begin to grow and replace normal tissue (AICA., 2013). The potential of using natural products as anticancer agents was recognized in the 1950s by the U.S. National Cancer Institute (NCI) and has made major contributions to the discovery of new naturally occurring anticancer agents.

Peucedanum japonicum Thunb. is a perennial herb found distributed throughout Korea, Japan, the Philippines, China, and Taiwan. P. japonicum is a perennial plant that grows to a height of $60 \sim 100 \mathrm{~cm}$. The leaves are frequently served as a vegetable or a garnish for raw fish in Korea. The root of the plant is utilized in the treatment of cough, cold, headache, and also as an anodyne (Ikesshiro et al., 1992, 1993). The chemical constituents of $P$. japonicum have already been studied to some degree, and the khellactone coumarins were identified as the characteristic components. Examinations of the $P$. japonicum roots have resulted in the isolation of four new khellactone esters and 17 other compounds: isoimperatorin, psoralen, bergapten, xanthotoxol, eugenin, cnidilin, (-)-selinidin, (-)-deltoin, $(+)$-pteryxin, $(+)$-peucedanocoumarin III, xanthotoxin, imperatorin, (-)-hamaudol, (+)-visamminol, (+)-marmesin, $(+)$-oxypeucedanin hydrate and (+)-peucedanol (Chen et al., 1995). Some of the coumarins isolated from $P$. japonicum have been reported to evidence antiplatelet (Baba et al., 1989; Chen et al., 1996; Hsiao et al., 1998; Jong et al., 1992), antiallergic (Takeuchi et al., 1991), antagonistic, and spasmolytic (Aida et al., 1998) activities. P. japonicum leaf extracts are reported to have strong antioxidant activity (Hisamoto et al., 2002). Moreover, hyuganin $\mathrm{C}$ isolated from the stem of $P$. japonicum has been reported to have anticancer activity (Jang et al., 2008) and it exhibits the highest activity in HL-60 cells $\left(\mathrm{IC}_{50}=13.2 \mu \mathrm{g} / \mathrm{mL}\right)$ and A549 cells $\left(\mathrm{IC}_{50}=18.1 \mu \mathrm{g} / \mathrm{mL}\right)$. However, the identification of anticancer compounds has never previously been reported from $P$. japonicum roots.

In this study, we report the isolation of two compounds from $P$. japonicum roots and their structures as determined via spectroscopic methods. Additionally, the isolated compound was evaluated for its cytotoxic activity against selected cancer cell lines.

\section{Materials and Methods}

\section{Plant material}

Roots of P. japonicum were collected from wild populations growing on Jeju Island in July.

\section{Reagents}

RPMI 1640 medium, Dulbecco's modified Eagle's medium (DMEM), trypsin/EDTA, fetal bovine serum (FBS), penicillin, and streptomycin were purchased from Invitrogen Life Technologies Inc. (Grand Island, NY, USA). Dimethyl sulfoxide (DMSO) and MTT were purchased from Sigma Chemical Co. (St. Louis, MO, USA). UPLC-grade water and acetonitrile were purchased from EMD Chemicals (Darmstadt, Germany).

\section{Instruments}

UV spectra were measured on a Varian Cary100 spectrophotometer. ${ }^{1} \mathrm{H}-\mathrm{NMR}$ and ${ }^{13} \mathrm{C}$-NMR at $500 \mathrm{MHz}$ were obtained with a Bruker AM 500 spectrometer in $\mathrm{CDCl}_{3}$. EIMS was obtained on a JEOLJMS-700 mass spectrometer. TLC was conducted on precoated Kieselgel $60 \mathrm{~F}_{254}$ plates (Art. 5715; Merck) and the spots were detected either by examining the plates under a UV lamp or by treating the plates with a $10 \%$ ethanolic solution of phosphomolybdic acid (Wako Pure Chemical Industries) followed by heating at $110^{\circ} \mathrm{C}$. UPLC was conducted using a Waters US/ACQUITY UPLC Module, Waters US/ACQUITY UPLC Photodiode PDA Detector and Bondapak ${ }^{\mathrm{TM}} \mathrm{C}_{18}$ column $(1.7 \mathrm{M} 2.1 \times 150$ $\mathrm{mm}$ ) (Waters, Ireland).

\section{Cell culture}

HeLa (Human cervix cancer cells), HepG2 (Human hepatoblastoma cancer cells), and CCD-25Lu (Human normal lung fibroblast cell) cells were cultured at $37^{\circ} \mathrm{C}$ in a humidified 
atmosphere of $5 \% \mathrm{CO}_{2}$ in DMEM containing $10 \%$ heat-inactivated FBS, $100 \mathrm{U} / \mathrm{mL}$ of penicillin, and $100 \mathrm{mg} / \mathrm{mL}$ of streptomycin. SNU-16, AGS (Human gastric carcinoma cells) cells were cultured at $37^{\circ} \mathrm{C}$ in a humidified atmosphere of $5 \% \mathrm{CO}_{2}$ in RPMI 1640 containing 10\% heat-inactivated FBS, $100 \mathrm{U} / \mathrm{mL}$ of penicillin, and $100 \mathrm{mg} / \mathrm{mL}$ of streptomycin. Exponentially growing cells were treated with various concentrations of compounds I and II as indicated.

\section{Extraction and isolation}

Ten kilograms of $P$. japonicum roots were air-dried, chopped, and extracted three times with $100 \% \mathrm{MeOH}(72 \mathrm{~L})$ for 14 days at room temperature. The combined extract was then evaporated to dryness under reduced pressure at a temperature below $40^{\circ} \mathrm{C}$. After filtration and concentration, the resultant extract (326 g) was suspended in $\mathrm{H}_{2} \mathrm{O}(2 \times 300$ $\mathrm{mL})$ and partitioned with organic solvents $\left(\mathrm{CHCl}_{3}, \mathrm{BuOH}\right)$ of different polarities to generate soluble-chloroform $\left(\mathrm{CHCl}_{3}\right.$, $84 \mathrm{~g})$, soluble-butanol ( $\mathrm{BuOH}, 168 \mathrm{~g})$, and soluble-water $\left(\mathrm{H}_{2} \mathrm{O}, 74 \mathrm{~g}\right)$ layers, respectively. The $\mathrm{CHCl}_{3}$ layers were then subjected to column chromatography using silica gel with a methylene chloride $\left(\mathrm{CH}_{2} \mathrm{Cl}_{2}\right)$ : ether $\left(\mathrm{Et}_{2} \mathrm{O}\right)$ gradient to yield eight fractions (P1-P8). The seventh fraction (P7) (2.9 g) was subjected to silica gel column chromatography with $n$-hexane : acetone $(5: 1 \rightarrow 1: 2)$ to generate 12 subfractions. Subfractions 1-5 were subjected to silica gel chromatography (n-hexane : Acetone $=5: 1 \rightarrow 1: 2$ ) and purified by recrystallization to yield (10E)1,10-heptadecadiene-4,6-diyne-3,8,9-triol (24 mg). The fourth fraction (P4) (4 g) was subjected to silica gel column chromatography with $n$-hexane : ethyl acetoacetate $(15: 1 \rightarrow$ $1: 4$ ) to yield 35 subfractions. Subfractions 1 - 4 were subjected to silica gel chromatography (n-hexane : ethyl acetoacetate $=$ $10: 1 \rightarrow 1: 4$ ) and purified by recrystallization to generate anomalin $(67 \mathrm{mg})$.

\section{UPLC apparatus and measurements}

The roots of $P$. japonicum $(10 \mathrm{~g})$ were extracted with $100 \mathrm{~mL}$ of $\mathrm{MeOH}$ overnight in a vortex mixer at room temperature to form the final extract, which was subsequently centrifuged. The extracts employed for UPLC analysis were first passed through a $0.20 \mu \mathrm{m}$ filter (Advantec MFS, Inc. CA, USA) prior to being injected into a reverse phase $\mu$ Bondapak $^{\mathrm{TM}} \mathrm{C}_{18}$. A 20 $\mu \mathrm{L}$ portion of these solutions was injected into the UPLC system. The mobile phase was water containing $0.1 \%$ formic acid (A) and acetonitrile (B). A linear gradient of A - B was used $(0 \min 80: 20,2.5 \min 80: 20,6 \min 40: 60,8 \min 0$ : $100,8.50 \min 0: 100,9 \min 80: 20 \mathrm{v} / \mathrm{v}$ ). The flow rate was adjusted to $0.4 \mathrm{~mL} / \mathrm{min}$ and the detection wavelength was set to $310 \mathrm{~nm}$, while the temperature was held constant at $30^{\circ} \mathrm{C}$.

\section{Standard solution and calibration curves}

An external standard method was utilized for quantification. Approximately 5 10 mg of a standard was dissolved in a $10 \mathrm{~mL}$ volumetric flask with $\mathrm{MeOH}$ to obtain a stock solution, then stored in a freezer. The working standard solutions were diluted to a series of concentrations with $\mathrm{MeOH}$. The mean areas generated from the standard solutions were plotted against the concentrations to establish the calibration equations.

\section{Cell viability assay}

The effects of the roots of $P$. japonicum on the viability of a variety of cancer cell lines were determined via an MTT-based assay (Hansan et al., 1989). In brief, exponential-phase cells were collected and transferred to microtiter plates. The cells were then incubated for 72 hours in the presence of various concentrations of $P$. japonicum root. After incubation, $5 \mathrm{mg} / \mathrm{mL}$ of MTT solution (Sigma, MO, USA) was added to each well and the cells were incubated for $4 \mathrm{~h}$ at $37^{\circ} \mathrm{C}$. The plates were then centrifuged for $20 \mathrm{~min}$ at 2,500 rpm at room temperature, and the medium was carefully removed. DMSO $(150 \mathrm{~mL})$ was then added to each well to dissolve the formazan crystals. The plates were immediately read at $570 \mathrm{~nm}$ on a Sunrise microplate reader (Sunrise, Tecan, Salzburg, Austria).

\section{Results and Discussion}

The $P$. japonicum roots were extracted with $100 \% \mathrm{MeOH}$. After filtration and concentration the resulting extracts were suspended in $\mathrm{H}_{2} \mathrm{O}$ and successively partitioned with $\mathrm{CHCl}_{3}$ and $n-\mathrm{BuOH}$, generating $\mathrm{CHCl}_{3}-$ and $n-\mathrm{BuOH}$-extractable residues. The two compounds were isolated via repeated chromatographic separation of the $\mathrm{CHCl}_{3}$ fractions, showed cytotoxic activity. The compounds were then structurally identified via the interpretation of several sets of spectral 
data, and compared with the data described in the literature.

The exact structure of compound I was inferred from a detailed analysis of the ${ }^{1} \mathrm{H}$ and ${ }^{13} \mathrm{C}$-NMR data, along with the

Table 1. NMR data of compound I $\left(500 \mathrm{MHz}, \mathrm{CDCl}_{3}\right)^{\mathrm{z}}$

\begin{tabular}{ccc}
\hline \hline Position & ${ }^{1} \mathrm{H}$ & ${ }^{13} \mathrm{C}^{\mathrm{y}}$ \\
\hline 1 & & $117.6(\mathrm{~s})$ \\
2 & $5.92(1 \mathrm{H}, \mathrm{m})$ & $135.9(\mathrm{~d})$ \\
3 & $4.90(1 \mathrm{H}, \mathrm{m})$ & $63.7(\mathrm{~d})$ \\
4 & & $78.2(\mathrm{~s})$ \\
5 & & $70.3(\mathrm{~s})$ \\
6 & & $70.4(\mathrm{~s})$ \\
7 & & $78.1(\mathrm{~s})$ \\
8 & $4.23(1 \mathrm{H}, \mathrm{d})$ & $66.7(\mathrm{~d})$ \\
9 & $4.10(1 \mathrm{H}, \mathrm{dd})$ & $75.7(\mathrm{~d})$ \\
10 & $5.85(1 \mathrm{H}, \mathrm{m})$ & $136.8(\mathrm{~d})$ \\
11 & $(1 \mathrm{H}, \mathrm{d}, \mathrm{J}=6.5 \mathrm{~Hz})$ & $126.9(\mathrm{~d})$ \\
12 & $5.46(2 \mathrm{H}, \mathrm{m})$ & $32.5(\mathrm{t})$ \\
13 & $1.36(2 \mathrm{H}, \mathrm{m})$ & $29.1(\mathrm{t})$ \\
14 & $1.25(2 \mathrm{H}, \mathrm{m})$ & $29.0(\mathrm{t})$ \\
15 & $1.25(2 \mathrm{H}, \mathrm{m})$ & $31.9(\mathrm{t})$ \\
16 & $1.25(2 \mathrm{H}, \mathrm{m})$ & $28.8(\mathrm{t})$ \\
17 & $0.85(3 \mathrm{H}, \mathrm{m})$ & $14.3(\mathrm{q})$ \\
$1 \mathrm{a}$ & $5.23(1 \mathrm{H}, \mathrm{d}, J=10.0 \mathrm{~Hz})$ & \\
$1 \mathrm{~b}$ & $5.43(1 \mathrm{H}, \mathrm{m})$ & \\
\hline
\end{tabular}

${ }^{z}$ Assignments were made by ${ }^{1} \mathrm{H}-{ }^{1} \mathrm{H}$ COSY, HMQC, and HMBC data.

${ }^{\mathrm{y}}$ Multiplicity was established from DEPT data.
2D-NMR experiments. The ${ }^{1} \mathrm{H}$ and ${ }^{13} \mathrm{C}$-NMR data with DEPT experiments showed the presence of 17 carbon atoms as one $\mathrm{sp}^{2}$ methylene $\left(\delta_{\mathrm{C}} 117.6, \mathrm{C}-1\right)$ five $\mathrm{sp}^{3}$ methylenes $\left(\delta_{\mathrm{C}}(32.5\right.$, C-12), (29.1, C-13), (29.0, C-14), (31.9, C-15), (22.8, C-16)), one methyl carbons $\left(\delta_{\mathrm{C}} 14.3, \mathrm{C}-17\right)$, three methins $\left(\delta_{\mathrm{C}}(63.7\right.$, $\mathrm{C}-3),(136.8, \mathrm{C}-10),(126.9, \mathrm{C}-11))$ and four quaternary carbons $\left(\delta_{\mathrm{C}}(78.2, \mathrm{C}-4),(78.1, \mathrm{C}-7),(70.3, \mathrm{C}-5),(70.4, \mathrm{C}-6)\right)$. The ${ }^{1} \mathrm{H}-\mathrm{NMR}$ data showed the evidence for five methylene protons $\left(\delta_{\mathrm{H}} 5.46(2 \mathrm{H}, \mathrm{m}, \mathrm{H}-12), 1.36(2 \mathrm{H}, \mathrm{m}, \mathrm{H}-13), 1.25\right.$ $(6 \mathrm{H}, \mathrm{m} \mathrm{H}-14,15,16))$, one methyl group $\left(\delta_{\mathrm{H}} 0.85(3 \mathrm{H}, \mathrm{m}\right.$, $\mathrm{H}-17)$ ), and five olefinic protons $\left(\delta_{\mathrm{H}} 5.92(1 \mathrm{H}, \mathrm{m}, \mathrm{H}-2), 5.85\right.$ (1H, m, H-10), 5.48 (1H, d, $J=6.5 \mathrm{~Hz}, \mathrm{H}-11), 5.43$ (1H, m, $\mathrm{H}-1 \mathrm{~b}), 5.23$ (1H, d, $J=10.0 \mathrm{~Hz}, \mathrm{H}-1 \mathrm{a})$ ) (Table 1 and Fig. 1). Compound I was obtained as an amorphous yellow powder with the molecular formula of $\mathrm{C}_{17} \mathrm{H}_{24} \mathrm{O}_{3}$ and a molecular ion peak at $\mathrm{m} / \mathrm{z} 276$. Thus, based on all the above obtained spectral data, compound I was identified as (10E) 1,10heptadecadiene-4,6-diyne-3,8,9-triol (Fig. 2). (10E) 1,10heptadecadiene-4,6-diyne-3,8,9-triol was isolated from Glehnia littoralis ( Matsuura et al., 1996). But it was the first time that this compound was isolated from the roots of $P$. japonicum.

Compound II was inferred from a detailed analysis of the ${ }^{1} \mathrm{H}$ and ${ }^{13} \mathrm{C}$-NMR data, coupled with the 2D-NMR experiments. The ${ }^{1} \mathrm{H}$ and ${ }^{13} \mathrm{C}$-NMR data with DEPT experiments revealed the presence of 27 carbon atoms as four $\mathrm{sp}^{3}$ methylenes $\left(\delta_{\mathrm{C}}\right.$ (27.6, gem- $\left.\mathrm{CH}_{3}\right)$, (25.2, gem- $\left.\mathrm{CH}_{3}\right),\left(22.8\right.$, angeloyl- $\left.\mathrm{CH}_{3}\right)$, (20.5, angeloyl- $\left.\mathrm{CH}_{3}\right)$ ), four methins $\left(\delta_{\mathrm{C}}(143.3, \mathrm{C}-4),(129.1\right.$,
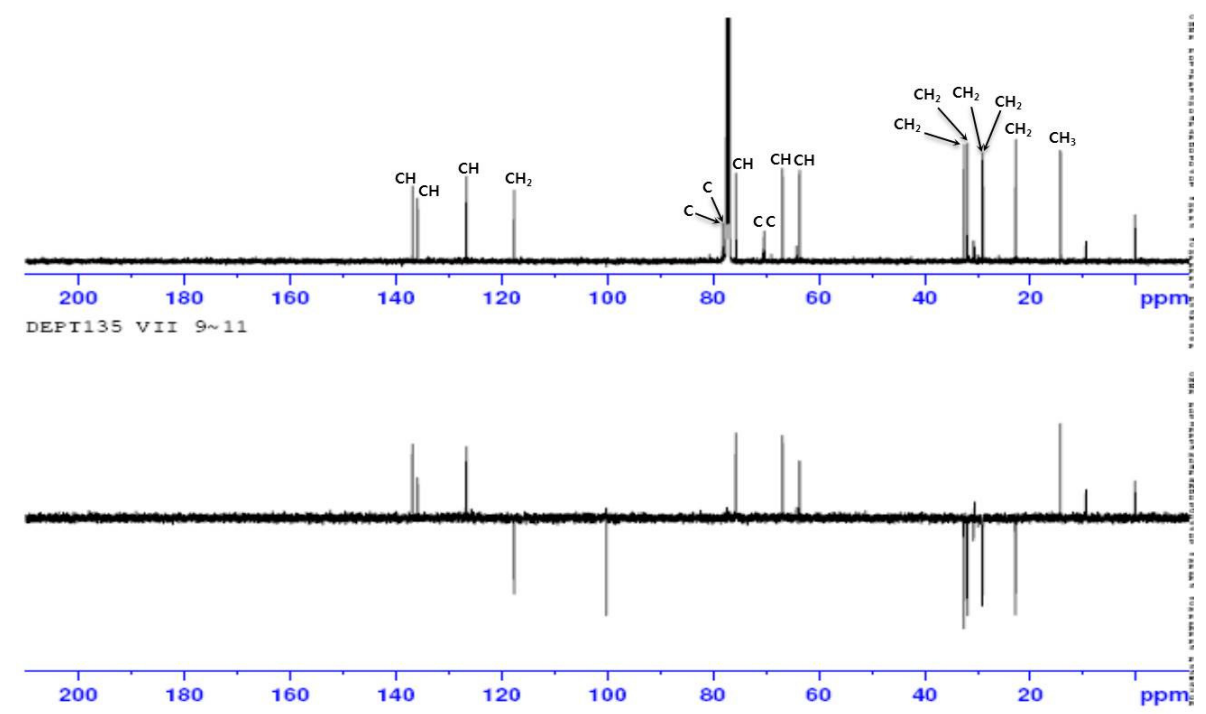

Fig. 1. DEPT spectrums of compound I (500 MHz, $\left.\mathrm{CDCl}_{3}\right)$. 


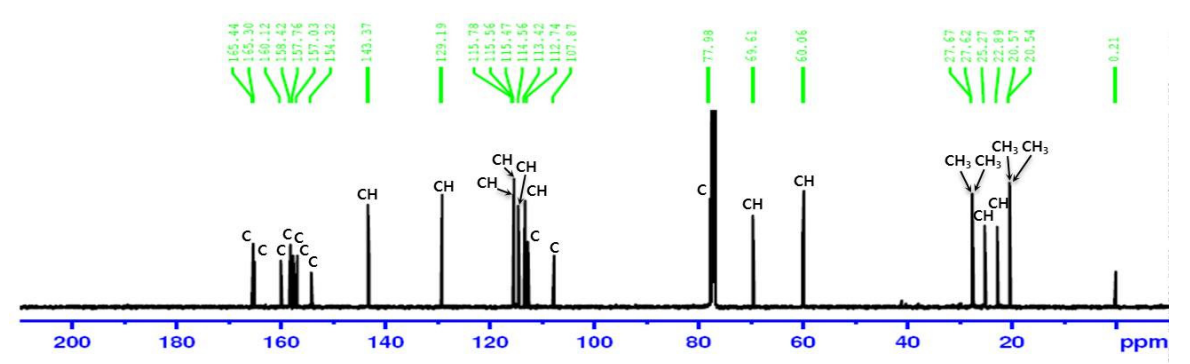

DEPT135 J CHC13_XI9_10

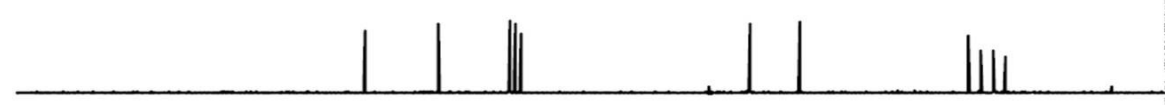

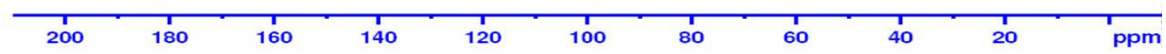

Fig. 2. Structures of isolated Compound I from P. japonicum roots.

Table 2. NMR data of compound II $\left(500 \mathrm{MHz}, \mathrm{CDCl}^{3}\right)^{\mathrm{z}}$

\begin{tabular}{ccc}
\hline \hline Position & ${ }^{1} \mathrm{H}$ & ${ }^{13} \mathrm{C}^{\mathrm{y}}$ \\
\hline 2 & & $160.1(\mathrm{~s})$ \\
3 & $6.17(1 \mathrm{H}, \mathrm{d}, J=9.5 \mathrm{~Hz})$ & $113.4(\mathrm{~d})$ \\
4 & $7.55(1 \mathrm{H}, \mathrm{d}, J=9.5 \mathrm{~Hz})$ & $143.3(\mathrm{~d})$ \\
5 & $7.31(1 \mathrm{H}, \mathrm{d}, J=9.0 \mathrm{~Hz})$ & $129.1(\mathrm{~d})$ \\
6 & $6.77(1 \mathrm{H}, \mathrm{d}, J=8.5 \mathrm{~Hz})$ & $114.5(\mathrm{~d})$ \\
7 & & $157.0(\mathrm{~s})$ \\
8 & & $107.8(\mathrm{~s})$ \\
9 & & $154.3(\mathrm{~s})$ \\
10 & & $112.7(\mathrm{~s})$ \\
2 & & $77.9(\mathrm{~s})$ \\
$3^{\prime}$ & & $69.6(\mathrm{~d})$ \\
4 & $5.33(1 \mathrm{H}, \mathrm{d})$ & $60.0(\mathrm{~d})$ \\
\hline
\end{tabular}

${ }^{\mathrm{z}}$ Assignments were made by ${ }^{1} \mathrm{H}-{ }^{1} \mathrm{H}$ COSY, HMQC, and $\mathrm{HMBC}$ data.

${ }^{\mathrm{y}}$ Multiplicity was established from DEPT data.

C-5), (114.5, C-6), (113.4, C-3)) and four quaternary carbons $\left(\delta_{\mathrm{C}}(157.0, \mathrm{C}-7),(154.3, \mathrm{C}-9),(112.7, \mathrm{C}-10),(107.8, \mathrm{C}-8)\right)$. The ${ }^{1} \mathrm{H}-\mathrm{NMR}$ data indicated the presence of five methylene protons $\left(\delta_{\mathrm{H}} 1.43\left(3 \mathrm{H}, \mathrm{s}\right.\right.$, gem- $\left.\mathrm{CH}_{3}\right), 1.39\left(3 \mathrm{H}, \mathrm{s}\right.$, gem- $\left.\mathrm{CH}_{3}\right)$, $2.14\left(6 \mathrm{H}, \mathrm{m}, \mathrm{CH}_{3}\right), 1.85\left(6 \mathrm{H}\right.$, angeloyl $\left.\left.-\mathrm{CH}_{3}\right)\right)$, and four aromatic protons $\left(\delta_{\mathrm{H}} 7.55(1 \mathrm{H}, \mathrm{d}, J=9.5 \mathrm{~Hz}, \mathrm{H}-4), 7.31(1 \mathrm{H}, \mathrm{d}, J=9.0\right.$ Hz, H-5), 6.77 (1H, d, $J=8.5$ Hz, H-6), 6.17 (1H, d, $J=9.5$ Hz, H-3)) (Table 2 and Fig. 3). Compound II was obtained as an amorphous yellow powder with the molecular formula $\mathrm{C}_{24} \mathrm{H}_{26} \mathrm{O}_{7}$. Thus, based on all the above obtained spectral data,

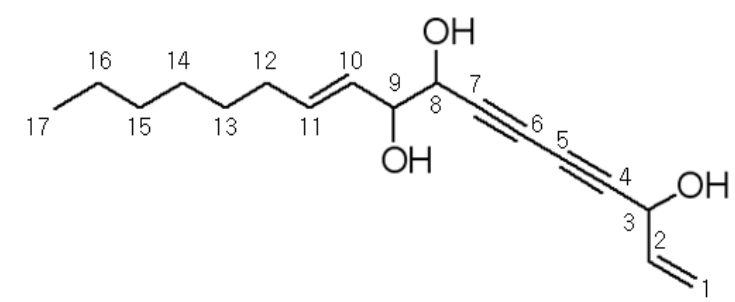

Fig. 3. DEPT spectrums of compound II (500 MHz, $\left.\mathrm{CDCl}_{3}\right)$.<smiles>C/C=C(/C)C(=O)O[C@H]1[C@H](OC(=O)/C(C)=C\C)c2c(ccc3ccc(=O)oc23)OC1(C)C</smiles>

Fig. 4. Structures of isolated Compound II from P. japonicum roots.

compound II was identified as anomalin (Fig. 4). Anomalin has been isolated previously from Saposhnikovia divaricata Schischk, Angelica flaccida Kommarov, and P. japonicum (Kim, 2008).

The effects of various concentrations of the (10E) 1,10heptadecadiene-4,6-diyne-3,8,9-triol (Comp. I) and anomalin (Comp. II) on the growth of HeLa, HepG2, AGS, and SNU-16 cells were evaluated via a MTT assay. The percent 


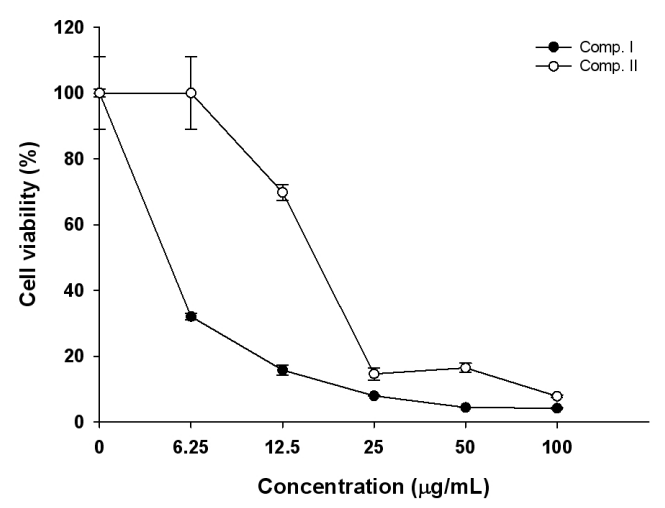

(A)

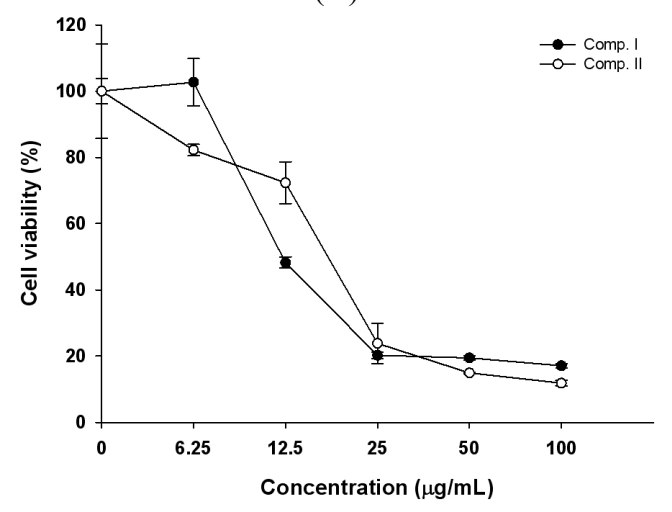

(C)

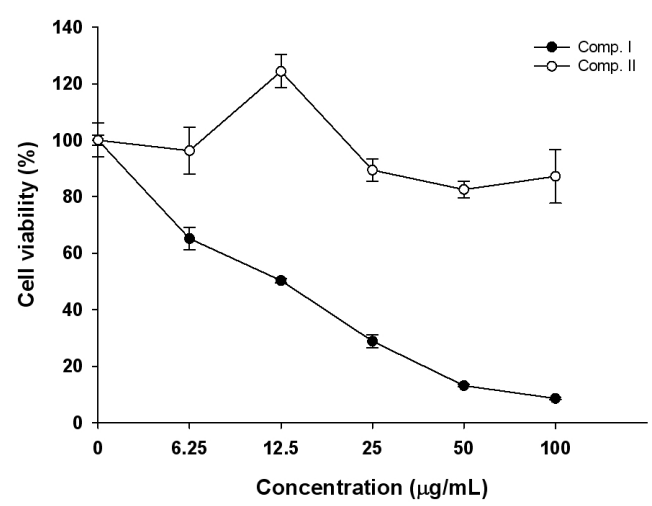

(B)

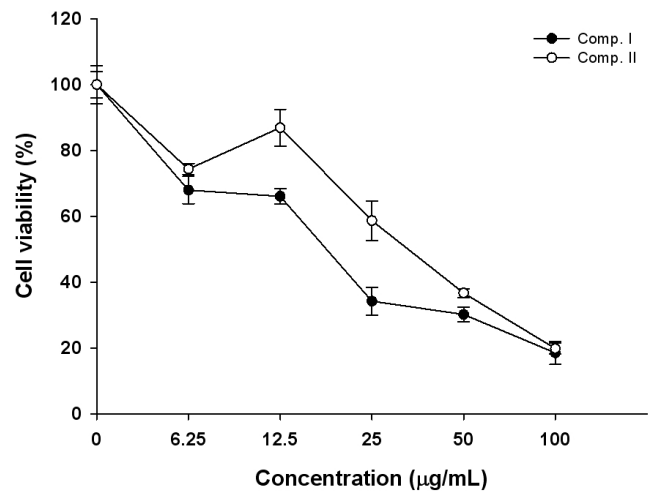

(D)

Fig. 5. Growth inhibition in cancer cell lines by Comp. I and Comp. II. (A) HeLa cells, plated at a density of $1 \times 10^{4}$ cells $/ \mathrm{mL}$, were incubated with various concentrations of Comp. I and Comp. II (6.25-100 $\mathrm{gg} / \mathrm{mL})$ for $48 \mathrm{hr}$; (B) HepG2 cells, plated at density of $1 \times$ $10^{4}$ cells $/ \mathrm{mL}$, were incubated with various concentrations of Comp. I and Comp. II (6.25-100 $\left.\mu \mathrm{g} / \mathrm{mL}\right)$ for $48 \mathrm{hr}$; (C) AGS cells, plated at density of $1 \times 10^{4}$ cells $/ \mathrm{mL}$, were incubated with various concentrations of Comp. I and Comp. II (6.25-100 $\mu \mathrm{g} / \mathrm{mL}$ ) for $48 \mathrm{hr}$; (D) SNU-16 cells, plated at a density of $1 \times 10^{4}$ cells $/ \mathrm{mL}$, were incubated for $48 \mathrm{~h}$ with various concentrations of Comp. I and Comp. II $(6.25-100 \mu \mathrm{g} / \mathrm{mL})$.

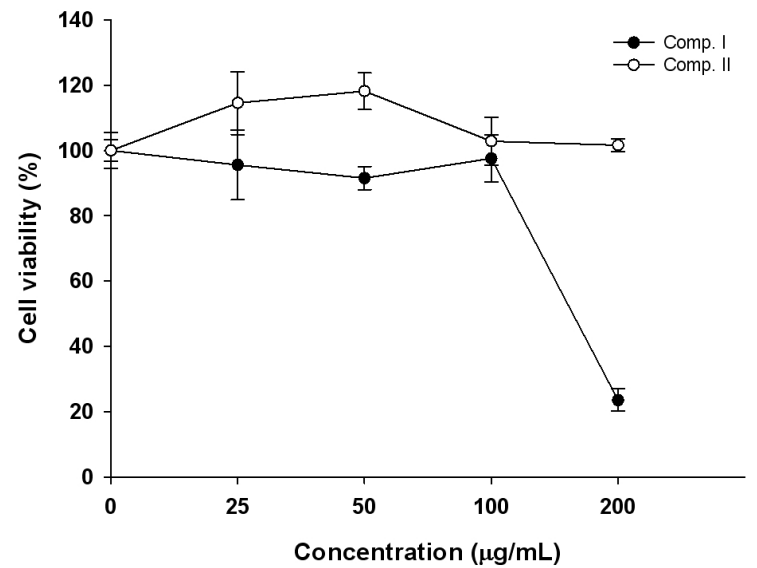

Fig. 6. Growth inhibition of CCD-25Lu Human normal lung fibroblast cell by Comp. I and Comp. II. CCD-25Lu cells, plated at density of $1 \times 10^{4}$ cells $/ \mathrm{mL}$, were incubated for $48 \mathrm{~h}$ with various concentrations of Comp. I and Comp. II $(25-200 \mu \mathrm{g} / \mathrm{mL})$. viabilities of all cells at $6.25,12.5,25,50$, and $100 \mathrm{mg} / \mathrm{mL}$ were reduced as compared with the controls. The inhibition of cell growth occurred in a dose-dependent fashion. Quercetin, chrysin, and linoleic acid were reported to evidence anticancer activity in these cell lines. HeLa and HepG2 cells were inhibited by $58 \%$ and $60 \%$ as the result of treatment with 25 $\mathrm{mg} / \mathrm{mL}$ of quercetin and chrysin, respectively (Ramos et al., 2008; Zhang, 2004). AGS cells were inhibited by $78 \%$ after treatment with $200 \mathrm{mg} / \mathrm{mL}$ of linoleic acid (Kwon et al., 2008). Comp. I evidenced the most potent cytotoxic activity against HeLa, HepG2, AGS, and SNU-16 cells. At a concentration of $25 \mathrm{mg} / \mathrm{mL}$, comp. I exhibited inhibitory activities of $69 \%, 92 \%$, and $78 \%$ on HeLa, HepG2, and SNU-16 cells, respectively. Additionally, at a concentration of $100 \mathrm{mg} / \mathrm{mL}$, Comp. I exerted an $82 \%$ inhibitory effect on AGS cells (Fig. 5). 


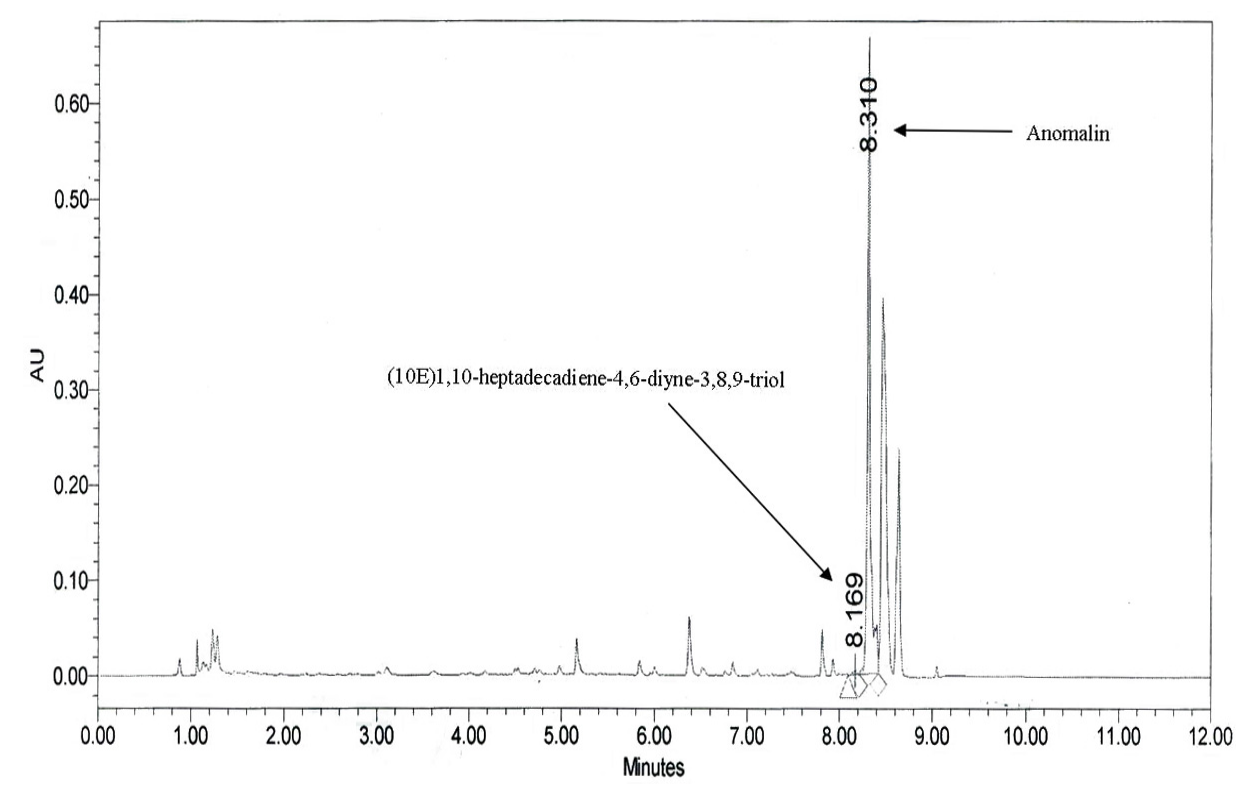

Fig. 7. Characteristic UPLC chromatogram. The mobile phase was water containing $0.1 \%$ formic acid (A) and acetonitrile (B). The linearly gradient of A - B (0 min, $80: 20 ; 2.5 \mathrm{~min}, 80: 20 ; 6 \mathrm{~min}, 40: 60 ; 8 \mathrm{~min}, 0: 100 ; 8.50 \mathrm{~min}, 0: 100 ; 9 \mathrm{~min}, 80: 20 \mathrm{v} / \mathrm{v})$. The flow rate was adjusted to $0.4 \mathrm{~mL} / \mathrm{min}$.

Comp. II also evidenced profound cytotoxic activity against HeLa and SNU-16 cells. At a concentration of $25 \mathrm{mg} / \mathrm{mL}$, Comp. II exerted inhibitory effects of $63 \%$ and $71 \%$ on HeLa and SNU-16 cells, respectively (Fig. 5). However, no significant cell death was noted in incubations of CCD25Lu with Comp. I and Comp.

II (Fig. 6). According to these results, Comp. I and Comp. II evidenced potent cytotoxic effects against several human cancer cell lines. Although Comp. I and Comp. II had been reported previously to exhibit antibacterial and antifungal properties (Matsuura, 1996), they have never been previously reported to exhibit anticancer activities.

The isolated (10E) 1,10-heptadecadiene-4,6-diyne-3,8,9-triol and anomalin were identified via comparisons of the physical and spectroscopic data with those of the authentic standard. They were also subjected to quantitative analysis using UPLC. The representative UPLC chromatogram is shown in Fig. 7. A calibration curve was constructed at different concentrations of (10E) 1,10-heptadecadiene-4,6-diyne-3,8,9-triol and anomalin $(6.25,12.5,25,50,100$, and $200 \mathrm{mg} / \mathrm{mL})$ as a standard. The results revealed that the root of $P$. japonicum contains 0.015 and $1.69 \mathrm{mg} / \mathrm{g}$ (dry weight) of (10E)1,10-heptadecadiene-4,6diyne-3,8,9-triol and anomalin, respectively.

\section{Acknowledgments}

This work was supported by "Cooperative Research Program for Agricultural Science \& Technology Development (Project No. PJ009470)", RDA, Republic of Korea, Rural Development Administration, Republic of Korea.

\section{References}

AICR. 2005. Food, Nutrition and the Prevention of cancer: A Global Perspective. http://www.aicr.org/

Aida, Y., T. Kasama, N. Takeuchi, M. Chiba and S. Tobinaga. 1998. Pharmacological activities of khellactones, compounds isolated from Peucedanum japonicum Thunb. and Peucedanum praeruptorium Dunn. Methods Find. Exp. Clin. Pharmacol. 20:343-351.

American Institute for Cancer Research, Washington DC. http://www.aicr.org/

Baba, K., Y. Yoneda, M. Kozawa, E. Fujita, N.H. Wang and C.Q. Yuan. 1989. Coumarins and antiplatelet aggregation constituents from formosan Peucedanum japonicum. Shoyakugaku Zasshi. 43:216.

Chen, I.S., C.T. Chang, W.S. Sheen, C.M. Teng, I.L. Tsai, C.Y. Duh and F.N. Ko. 1996. Coumarins and antiplatelet aggregation 
constituents from Formosan Peucedanum japonicum. Phytochemistry 41:525-530.

Hansan, M.B., S.E. Nielsen and K. Berg. 1989. Re-examination and further development of a precise and rapid dye method for measuring cell growth/cell kill. J. Immunol. Method 19:203-210.

Hisamoto, M., H. Kikuzaki, S. Yonemori and N. Nakatani. 2002. Antioxidant activity of tropical plant leaves traditionally used for food preservation in Okinawa. ITE Lett. 3:63-68.

Hsiao, G., F.N. Ko, T.T. Jong and C.M. Teng. 1998. Antiplatelet action of 3',4'-diisovalerylkhellactone diester purified from Peucedanum japonicum Thunb. Biol. Pharm. Bull. 21:688-692.

Ikeshiro, Y., I. Mase and Y. Tomita. 1992. Dihydropyranocoumarins from roots of Peucedanum japonicum. Phytochemistry 31:4303.

Ikeshiro, Y., I. Mase and Y. Tomita. 1993. Dihydropyrano coumarins from Peucedanum japonicum. Phytochemistry $33: 1543$

Jang, K.C., S.-C. Kim, E.-Y. Song, Y.-C. Um, S.C. Kim and Y.J. Lee. 2008. Isolation and identification of anticancer and anti-inflammatory substances in Peucedanum japonicum Thunb. Acta Hort. 765:49-54.

Jong, T.T., H.C. Hwang, M.Y. Jean, T.S. Wu and C.M. Teng. 1992. An antiplatelet aggregation principle and X-ray structural analysis of cis-khellactone diester from Peucedanum japonicum. J. Nat. Prod. 55:1396- 1401.

Kim, S.J., Y.W. Chin, K.D. Yoon, M.Y. Ryu, M.H. Yang, J.H. Lee and J.W. Kim. 2008. Chemical constituents of Saposhnikovia divaricata. Kor. J. Pharmacogn. 39(4):357-364.
Kushi, L.H., T. Byers, C. Doyle, E. Bandera, M. McCullough, T. Gansler, K. Andews and M. Thun. 2006. American cancer society guidelines on nutrition and physical activity for cancer prevention: Reducing the risk of cancer with healthy food choices and physical activity. CA Cancer J. Clin. 56:254-281.

Matsuura, H.S., S.W. Farmer, R.E. Hancock and G.H.N. Towers. 1996. Antibacterial and antifungal polyyne compounds from Glehnia littoralis. Planta Medica 62(3):256-259.

Newman, D.J., G.Mg. Cragg and K.M. Snader. 2000. The influence of natural products upon drug discovery. Nat. Prod. Rep. 17:215-234.

Newman, D.J., G.M. Cragg and K.M. Snader. 2003. Natural Products as sources of new drugs over the period 1981-2002. J. Nat. Prod. 66:1022-1037.

Ramos, A.A., C.F. Lima, M.L. Pereira and F.M. Fernandes. 2008. Antigenotoxic effects of quercetin, rutin and ursolic acid on HepG2 cells: Evaluation by the comet assay. Toxicology Letters 177:66-73.

Takeuchi, N., T. Kasama, Y. Aida, J. Oki, I. Maruyama, K. Watanabe and S. Tobinaga. 1991. Pharmacological activities of the prenylcoumarins, developed from folk usage as a medicine of Peucedanum japonicum Thunb. Chem. Pharm. Bull. 39:1415-1421.

Zhang, T., X. Chen, L. Qu, J. Wu, R. Cui and Y. Zhao. 2004. Chrysin and its phosphate ester inhibit cell proliferation and induce apoptosis in Hela cells. Bioorg. Med. Chem. 12:60976105. 